JKEP

Vol 3, No 1, Mei 2018

ISSN: 2354-6042 (Print)

ISSN : 2354-6050 (Online)

\title{
Hubungan Pengetahuan Posyandu Lansia dan Dukungan Keluarga terhadap Kegiatan Posyandu Lansia
}

\author{
Keumalahayati, T.Alamsyah \\ Poltekkes Kemenkes Aceh \\ Email: k_mala70@yahoo.coid
}

\author{
Artikel history \\ Dikirim, Maret $10^{\text {th }}, 2018$ \\ Ditinjau, April $5^{\text {th }}, 2018$ \\ Diterima, April 20 $0^{\text {th }}, 2018$
}

\begin{abstract}
The Elderly Posyandu is a social organization that is engaged in fostering advanced health, health workers who serve elderly health and the wider community are a forum for the community supported by cross-sectoral collaboration. The purpose of this study was to determine the relationship between knowledge and family support for elderly Posyandu activities in Seuriget Village, Langsa Barat District, Langsa City in 2014. The research method used a crossectional research design. The population of this study was all usas aged 60-69 years totaling 79 people. The sample in this study was total sampling. The research instrument used was a questionnaire. The results of the study showed that $88.6 \%$ of respondents did not take part in the elderly posyandu activities, $72.2 \%$ of respondents were less knowledgeable and the majority of family support was 74.7\%. The chi-square test results showed knowledge with the elderly posyandu activities $(p=0.001)$, with a value of X2 count $=12,443>X 2=3.841$. There was a relationship between family support and elderly posyandu activities $(p=0.007)$ and the value X2 count $=9.069>X 2=3.841$. Suggestions for the results of the study can be input for the community and the elderly towards the importance of the elderly Posyandu and can be used as input for the research site on the importance of the elderly posyandu.
\end{abstract}

Keywords : Knowledge; support; family; posyandu; elderly.

\begin{abstract}
ABSTRAK
Posyandu Lanjut Usia adalah suatu organisasi sosial yang bergerak dalam pembinaan kesehatan usia lanjut, petugas kesehatan yang melayani kesehatan usia lanjut dan masyarakat luas merupakan wadah dari masyarakat yang didukung kerjasama lintas sektoral. Tujuan penelitian ini adalah untuk mengetahui hubungan pengetahuan dan dukungan keluarga terhadap kegiatan Posyandu Lansia di Desa Seuriget Kecamatan Langsa Barat Kota Langsa Tahun 2014. Desain penelitian adalah crossectional. Populasi penelitian ini adalah seluruh lansia berusia 60-69 tahun berjumlah 79 orang.
\end{abstract}


Sampel dalam penelitian ini adalah Total Sampling. Instrumen penelitian yang digunakan adalah kuesioner. Hasil penelitian menunjukkan 88,6\% lansia tidak mengikuti kegiatan posyandu lansia, 72,2\% lansia memiliki pengetahuan kurang dan $74,4 \%$ lansia mendapat dukungan keluarga. Hasil uji chi-square menujukkan pengetahuan dengan kegiatan posyandu lansia $(\mathrm{p}=0,001)$, dengan nilai $\mathrm{X}^{2}$ hitung $=$ $12,443>X^{2}=3,841$. Terdapat hubungan dukungan keluarga dengan kegiatan posyandu lansia $(p=0,007)$ dengan nilai $X^{2}$ hitung $=9,069>X^{2}=3,841$. Saran hasil penelitian dapat menjadi bahan masukan bagi masyarakat dan usia lanjut terhadap pentingnya Posyandu lansia dan dapat digunakan sebagai bahan masukan bagi tempat penelitian terhadap pentingnya posyandu lansia.

Kata Kunci : Pengetahuan; dukungan; keluarga; posyandu; lansia.

\section{PENDAHULUAN}

Menua $($ menjadi tua $=$ aging) adalah suatu proses menghilangnya secara perlahan-lahan kemampuan jaringan untuk memperbaiki diri dan mempertahankan struktur dan fungsi normalnya sehingga tidak dapat bertahan terhadap jenjang (termasuk infeksi) dan memperbaiki kerusakan yang diderita (Setiadi, 2012). Menjadi tua adalah suatu proses natural dan kadang-kadang tidak tampak mencolok. Penuaan akan terjadi pada semua sistem tubuh manusia dan tidak semua sistem akan mengalami kemunduran pada waktu yang sama. Meskipun proses menjadi tua merupakan gambaran yang universal, tidak seorangpun mengetahui dengan pasti penyebab penuaan atau mengapa manusia menjadi tua pada usia berbeda-beda (Budi, 2010).

Usia lanjut mempunyai dua karakteristik yaitu adanya proses penuaan dan adanya proses penyakit. Proses penuaan akan berpengaruh terhadap sistem imun dan juga akan berimplikasi klinis, sedangkan akibat dari proses penyakit yang tidak spesifik akan berimbas pada pemberian obat yang begitu komplek. Kedua proses diatas tentu saja usia lanjut akan mengalami gangguan baik itu dari segi fisik ataupun kognitifnya yang berakibat pada ketidakmampuan usia lanjut untuk dapat memenuhi kebutuhannya sendiri karena adanya keterbatasan dan akhirnya sampailah kepada kematian (Pramantara, 2011).

Proses menua akan menimbulkan perubahan-perubahan fisik, psikologi dan sosial akibat proses degeneratif yang muncul dengan seiring bertambahnya usia, sehingga akan menjadi tantangan bagi usia lanjut dan lingkungannya. Oleh karena itu kesehatan usia lanjut perlu mendapat 
perhatian keluarga, pemerintah dan tenaga kesehatan untuk mengurangi masalah-masalah yang mungkin timbul. Prevalensi gangguan pada usia lanjut: arthritis/peradangan pada sendi (46\%), hipertensi/tekanan darah lebih dari 140/90 mmHg (38\%), gangguan pendengaran (28\%), kelainan jantung (28\%), sinusitis kronis (18\%), penurunan visus (14\%), dan gangguan pada tulang (13\%) (Tamher, 2009).

Dampak pada berbagai aspek kehidupan, baik sosial, ekonomi, terutama kesehatan, dipengaruhi oleh proses penuaan penduduk karena dengan semakin bertambahnya usia, fungsi organ tubuh akan semakin menurun baik karena faktor alamiah maupun karena penyakit. Dengan demikian, peningkatan jumlah usia lanjut menjadi salah satu indikator keberhasilan pembangunan sekaligus sebagai tantangan dalam pembangunan. Bila permasalahan tersebut tidak diantisipasi dari sekarang, maka tidak tertutup kemungkinan bahwa proses pembangunan akan mengalami berbagai hambatan (Erfandi, 2009).

Populasi usia lanjut pada masa ini semakin meningkat, oleh karena itu pemerintah telah merumuskan berbagai kebijakan pelayanan kesehatan usia lanjut ditujukan untuk meningkatkan derajat kesehatan dan mutu kehidupan usia lanjut untuk mencapai masa tua yang bahagia dan berdaya guna dalam kehidupan keluarga dan masyarakat sesuai dengan keberadaannya. Sebagai wujud nyata pelayanan sosial dan kesehatan pada kelompok usia lanjut ini, pemerintah telah mencanangkan pelayanan pada usia lanjut melalui beberapa jenjang (Pramantara, 2011). Menurut Undang-Undang No. 13 tahun 1998 tentang kesejahteraan usia lanjut yang menyebutkan bahwa pelayanan kesehatan dimaksudkan untuk memelihara dan meningkatkan derajat kesehatan dan kemampuan usia lanjut, upaya penyuluhan, penyembuhan dan pengembangan lembaga. UndangUndang No.23 Tahun 1992 tentang Kesehatan, pasal 19 dan Peraturan Menteri Dalam Negeri Nomor 54 Tahun 2007 tentang penbentukan posyandu, menyebutkan bahwa kesehatan manusia usia lanjut diarahkan untuk memelihara dan meningkatkan kesehatan dan kemampuannya agar tetap produktif, serta pemerintah membantu penyelenggaraan upaya kesehatan usia lanjut untuk meningkatkan kualitas 
hidupnya secara optimal (Depkes RI, 2009).

Pemerintah telah mengantisipasi adanya pertambahan jumlah kelompok usia lanjut dengan mengadakan Pos Pelayanan Terpadu (Posyandu) Lansia yang dibina oleh Pusat Kesehatan Masyarakat (Puskesmas) yang tersebar diberbagai wilayah di Indonesia. Tujuan dari posyandu Lansia tersebut adalah untuk meningkatkan kualitas sumber daya manusia agar penduduk usia lanjut yang makin besar jumlahnya tidak hanya menjadi beban dalam keluarga, masyarakat atau negara, maka pelayanan untuk kelompok ini perlu semakin mendapat perhatian. Dengan demikian akan tercapai penduduk usia lanjut yang sehat, bahagia, berdaya guna, makin produktif serta tidak sakitsakitan (Depkes RI, 2010).

Posyandu lanjut usia adalah suatu wadah dari masyarakat dan untuk masyarakat yang didukung kerjasama lintas sektoral. Sasaran posyandu lanjut usia meliputi beberapa kelompok dimana ada sasaran langsung dan tidak langsung. Sasaran langsung adalah usia virilitas (pra senilis) 45 sampai dengan 59 tahun, usia lanjut 60 sampai dengan
69 tahun, dan usia lanjut resiko yaitu usia lebih dari 70 tahun. Sedangkan sasaran yang tidak langsung adalah keluarga dimana usia lanjut berada, masyarakat di lingkungan usia lanjut, organisasi sosial yang bergerak dalam pembinaan kesehatan usia lanjut, petugas kesehatan yang melayani kesehatan usia lanjut dan masyarakat luas (Depkes RI, 2009).

Kegiatan posyandu yang dilakukan setiap satu bulan sekali yang meliputi penimbangan berat badan, pengukuran tinggi badan, pemeriksaan tekanan darah, pemeriksaan kegiatan sehari-hari, pemeriksaan status mental, pemeriksaan haemoglobin, pemeriksaan reduksi urine, pemeriksaan protein urine, pemberian makanan tambahan dan kegiatan lain seperti olahraga (senam usia lanjut) yang dikelola kader posyandu. Pemeriksaan kesehatan usia lanjut, bukan sekedar memeriksa dan melakukan penimbangan terhadap berat badan dan pengukuran tekanan darah semata, lebih dari itu ini dilakukan untuk menggerakkan masyarakat, khususnya para usia lanjut agar mau menjaga kesehatan fisik, psikis dan spiritual mereka (Pramantara, 2011). Seiring dengan meningkatnya kualitas 
pelayanan sosial dan kesehatan populasi usia lanjut meningkat signifikan diberbagai negara. Diseluruh Asia diperkirakan bahwa jumlah usia lanjut akan meningkat 301,4\% dari 207 juta di tahun 2000 menjadi 857 juta di tahun 2050. Meningkatnya jumlah usia lanjut tersebut melatarbelakangi pelaksanaan Jakarta Forum on Social Protection Citizen in Indonesia And ASEAN Country. Penanganan usia lanjut di ASEAN harus disiapkan sejak sekarang agar tidak menjadi beban dimasa yang akan datang (WHO, 2010).

Secara demografi berdasarkan data sensus penduduk, Indonesia memasuki era penduduk berstruktur tua. Pada tahun 2020 diperkirakan penduduk usila di Indonesia mencapai 28,8 juta atau $11,34 \%$ dengan UHH sekitar 71,1 tahun. Dari jumlah tersebut pada tahun 2010 jumlah penduduk usila yang tinggal diperkotaan sebesar 12.380.321 $(9,58 \%)$ dan yang tinggal di pedesaan sebesar 15.612.232 (9,97\%). Namun jika dilihat pada tahun 2020 walaupun jumlah usila tetap mengalami kenaikan yaitu sebesar 28.822.879 (11,34\%), ternyata yang tinggal diperkotaan lebih besar yaitu sebanyak 15.714.952 $(11,20 \%)$ dibandingkan dengan yang tinggal di pedesaan yaitu sebesar 13.107.927 (11,51\%) (Badan Pusat Statistik, 2012).

Data Kesehatan Provinsi Aceh, jumlah lansia yang ada saat ini berjumlah 203.237 jiwa. Dengan persentase golongan umur 45-59 tahun sebanyak 95.247 (46,86\%), golongan umur 60-69 tahun sebanyak $82.537(40,6 \%)$, dan golongan umur $>70$ tahun sebanyak 25.966 (12,8\%) (Profil Dinas Kesehatan Provinsi Aceh Tahun 2012). Data dari Dinas Kesehatan Kota Langsa tahun 2012, jumlah usia lanjut yang mendapat pelayanan kesehatan sebesar 19.186 (49.02\%) dari seluruh populasi usia lanjut yang jumlahnya mencapai 39.141 jiwa. Dari Puskesmas Langsa Barat jumlah usia lanjut yang mendapatkan pelayanan kesehatan sebesar 2.717 $(15.06 \%)$ dari seluruh populasi usia lanjut yang jumlahnya mencapai 18.043 jiwa. (Profil Dinas Kesehatan Kota Langsa Tahun 2013).

Sedangkan data dari Desa Seuriget, jumlah usila sebanyak 350 jiwa. Dengan persentase golongan umur 4559 tahun sebanyak 263 jiwa, golongan umur 60-69 tahun sebanyak 79 jiwa, dan golongan umur $>70$ tahun sebanyak 
8 jiwa. Posyandu usia lanjut telah dibentuk sebanyak 1 posyandu tetapi jumlah kunjungan usia lanjut yang berkunjung di posyandu yang telah di bentuk yaitu berkisar sebanyak 4 sampai dengan 10 orang pada tahun 2013. Sedangkan jumlah usia lanjut yang berkunjung pada tahun 2014 berkisar sebanyak 5 orang dan yang dilakukan home visit sekitar 4 jiwa karena sudah terlalu tua dan tidak sanggup lagi ke posyandu (Laporan Desa Seuriget Tahun 2014). Hal tersebut menunjukkan bahwa kunjungan ke posyandu lansia masih sangat rendah berdasarkan jumlah kunjungan usia lanjut ke posyandu, jumlah usia lanjut yang dibina masih kurang dari target pencapaian cakupan pelayanan kesehatan usia lanjut pada tahun 2010 berdasarkan Standar Pelayanan Minimal (SPM) yaitu sebesar 40\% (Depkes RI, 2010).

Kegiatan promosi posyandu lansia di masyarakat masih sebatas informasi dari orang ke orang yang sudah pernah memanfaatkan kegiatan posyandu lansia ataupun informasi yang didapat saat mengunjungi posyandu lansia. Berdasarkan fenomena diatas maka peneliti tertarik untuk melakukan penelitian hubungan pengetahuan dan dukungan keluarga terhadap kegiatan posyandu lansia di Desa Seuriget Kecamatan Langsa Barat Kota Langsa Tahun 2014.

\section{METODE}

Penelitian bersifat analitik untuk mengetahui hubungan pengetahuan dan dukungan keluarga terhadap kegiatan posyandu lansia di Desa Seuriget Langsa Barat tahun 2014, dengan desain cross - sectional. Penelitian dilakukan pada tanggal $10 \mathrm{~s} / \mathrm{d} \quad 20$ Agustus 2014.

Populasi dalam penelitian adalah seluruh lansia berusia 60-69 tahun di Desa Seuriget Kecamatan Langsa Barat Kota Langsa Jumlah sampel 79 orang. Pengambilan sampel berdasarkan kriteria inklusi yaitu usila yang berusia 60-69 tahun, bersedia menjadi responden, bertempat tinggal di Desa Seuriget Kecamatan Langsa Barat Kota Langsa yaitu sebanyak 79 orang. Sampel dalam penelitian ini adalah total sampling. Instrumen penelitian berupa kuesioner yang terdiri dari beberapa pertanyaan. Uji yang digunakan adalah uji chi-square. 
Sebelum melakukan pengumpulan data, peneliti memberitahukan penjelasan, tujuan, dan manfaat penelitian kepada responden dan kemudian meminta kesediaan responden untuk diadakan penelitian terhadap dirinya. Bila bersedia menjadi responden, maka responden tersebut diminta menandatangani surat persetujuan atau informed concent yang sebelumnya telah dibaca oleh responden dan mengerti isi informed concent tersebut. Peneliti benar-benar melindungi hak-hak responden yang menyangkut privasi responden yaitu untuk menjamin kerahasiaan identitas responden dimana pada kuesioner tidak mencantumkan nama responden tetapi hanya memakai inisial.

\section{HASIL DAN PEMBAHASAN}

1. Pengetahuan posyandu lansia dan dukungan keluarga terhadap kegiatan lansia

Tabel 1 memperlihatkan hasil penelitian menunjukkan mayoritas responden tidak mengikuti kegiatan posyandu lansia. Sebagian besar responden $\quad(72,2 \%) \quad$ memiliki pengetahuan yang kurang tentang posyandu lansia. Mayoritas keluarga $(74,7 \%)$ memberikan dukungan terhadap Lansia dalam mengikuti kegiatan posyandu lansia di Desa Seuriget Kecamatan Langsa Barat.Hal ini memperlihatkan masih banyak responden yang tidak mengikuti kegiatan posyandu Lansia di Desa Seuriget, Kecamatan Langsa Barat, Kota Langsa, dibandingkan dengan responden yang mengikuti kegiatan posyandu lansia.

Penelitian sebelumnya yang juga memperoleh hasil serupa adalah penelitian Siti Hajar (2011), yang melaporkan bahwa hambatan mengikuti kegiatan posyandu lansia yaitu pendidikan usia lanjut yang rendah, pengetahuan usia lanjut yang kurang tentang manfaat posyandu, sikap usia lanjut yang negatif tentang posyandu usia lanjut dan kurangnya dukungan keluarga usia lanjut. Dukungan keluarga juga merupakan suatu hal yang sangat dibutuhkan oleh lansia dalam mengikuti kegiatan posyandu seperti mengantar, mendampingi lansia saat mengikuti kegiatan posyandu. 
Tabel 1

Pengetahuan dan Dukungan Keluarga terhadap Kegiatan Posyandu

\begin{tabular}{lcc}
\hline \multicolumn{1}{c}{ Variabel } & f & \% \\
\hline Kegiatan Posyandu Lansia & 9 & 11,4 \\
$\quad$ Ada & 70 & 88,6 \\
$\quad$ Tidak Ada & & \\
Pengetahuan Lansia tentang Posyandu Lansia & 22 & 27,8 \\
$\quad$ Baik & 57 & 72,2 \\
Kurang & & \\
Dukungan Keluarga terhadap Kegiatan Posyandu & 20 & 25,3 \\
$\quad$ Mendukung & 59 & 74,7 \\
Tidak mendukung & 79 & 100 \\
\hline
\end{tabular}

Penelitian lainnya yang sesuai adalah penelitian Zakaria (2009), yang menunjukkan bahwa usila yang memanfaatkan posyandu semakin berkurang disebabkan sikap negatif lansia tentang posyandu usila. Hal ini dibuktikan dari penelitian di Puskesmas Mojo Kecamatan Gubang Surabaya, yang menunjukkan bahwa pemanfaatan posyandu lansia sangat rendah. Kunjungan oleh lansia sakit sebanyak $17,9 \%$ dan tidak sakit sebanyak 2,1\%. Keadaan ini memperlihatkan kecendrungan pemanfaatan pelayanan kesehatan di posyandu lansia yang sangat rendah, dan keaktifan lansia dalam mengikuti posyandu pun juga sangat rendah. Anggapan lansia bahwa fungsi posyandu ini sama dengan fungsi dari puskesmas dimana lansia akan mengikuti atau mengunjungi posyandu apabila lansia tersebut mengalami keluhan - keluhan mengenai kesehatannya.

Kondisi di atas disebabkan oleh karena kurangnya pengetahuan usia lanjut itu sendiri bahkan keluarga serta masyarakat belum memahami dan mengetahui akan adanya kegiatan posyandu lansia serta tujuan dari kegiatan tersebut. Karena kegiatan promosi posyandu usia lanjut di masyarakat masih sebatas informasi dari orang ke orang yang sudah pernah memanfaatkan kegiatan posyandu usia 
lanjut ataupun informasi yang didapat saat mengunjungi posyandu usia lanjut.

Emy (2012), mengemukakan bahwa Posyandu lansia adalah pos pelayanan terpadu untuk masyarakat usia lanjut di suatu wilayah tertentu yang sudah disepakati, yang digerakkan oleh masyarakat dimana mereka bisa mendapatkan pelayanan kesehatan. Posyandu usia lanjut merupakan pengembangan dari kebijakan pemerintah melalui pelayanan kesehatan bagi usia lanjut yang penyelenggaraannya melalui program puskesmas dengan melibatkan peran serta para usia lanjut, keluarga, tokoh masyarakat dan organisasi sosial dalam penyelenggaraannya.

Peneliti berasumsi bahwa sebagian besar responden tidak mau mengikuti kegiatan posyandu lansia, hal ini diakibatkan oleh beberapa faktor yaitu jarak rumah dengan posyandu dan puskesmas sama jaraknya dimana puskesmas Langsa Barat juga terletak di desa Seuriget sehingga Lansia sering berkunjung ke puseksmas di bandingkan dengan ke posyandu dimana kalau ke puskesmas lansia dapat berkunjung setiap hari kerja apabila mengalami keluhan - keluhan mengenai status kesehatannya sedangkan posyandu hanya di laksanakan satu kali dalam sebulan, sehingga lansia jarang memanfaatkan posyandu, kemudian pengetahuan yang kurang, tidak pernah mendapatkan informasi, dan kurangnya dukungan keluarga yang akan berdampak terhadap rendahnya tingkat kunjungan lansia ke posyandu lansia.

\section{Hubungan Pengetahuan Lansia} dengan Kegiatan Posyandu Lansia

Tabel 2 menunjukkan dari semua lansia yang memiliki pengetahuan baik, terdapat $68,2 \%$ yang tidak mengikuti kegiatan posyandu lansia. pengetahuan baik mayoritas dan hanya $31,8 \%$ yang mengikuti kegiatan posyandu lansia. Dari semua lansia yang memiliki pengetahuan yang kurang, $96,5 \%$ tidak mengikuti kegiatan posyandu dan hanya 3,5\% yang mengikuti kegiatan posyandu. Hasil uji beda proporsi dengan df $=1$ mengunakan uji Chi-Square $\left(\mathrm{X}^{2}\right)$ dengan tingkat kepercayaan 95\% menunjukkan adanya hubungan pengetahuan dengan kegiatan posyandu lansia di Desa Seuriget $(\mathrm{p}=$ 0,001), dengan nilai $X^{2}$ hitung $=$ $12,443>X^{2}=3,841$. 
Tabel 2

Hubungan Pengetahuan Lansia dengan Kegiatan Posyandu Lansia (n=79)

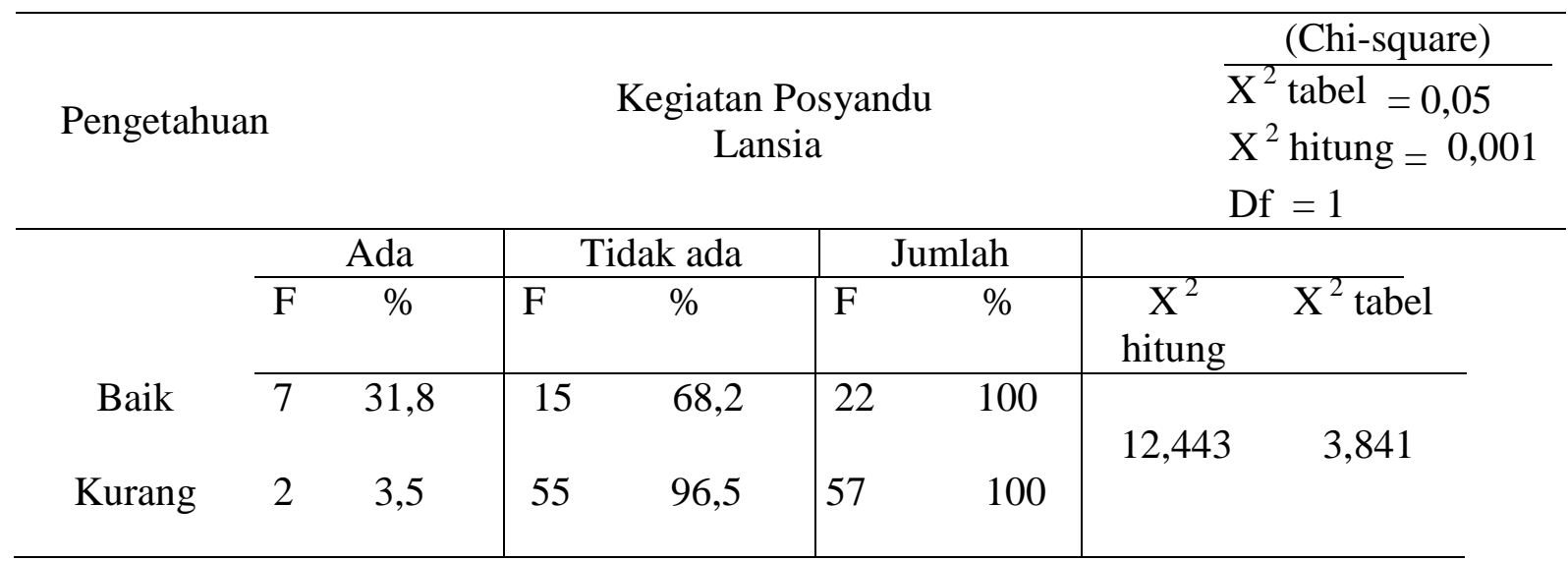

Berdasarkan hasil penelitian di atas hwa terdapat hubungan antara pengetahuan lansia dengan keikutsertaan lansia dalam kegiatan posyandu lansia. Notoatmodjo (2010), mengemukakan bahwa pengetahuan adalah hasil pengindraan manusia, atau hasil tahu seseorang terhadap objek melalui indra yang dimilikinya (mata, telinga, hidung, kulit). Dengan sendirinya pada waktu pengindraan sehingga menghasilkan pengetahuan tersebut sangat dipengaruhi oeh intensitas perhatian dan persepsi terhadap objek. Sebagian besar pengetahuan seseorang diperoleh melalui indra pendengaran (telinga) dan indra penglihatan (mata). Pengetahuan seseorang terhadap objek mempunyai intensitas atau tingkat yang berbeda-beda.
Penelitian sebelumnya yang berhubungan dengan posyandu usia lanjut, Sigit (2010) dengan judul penelitian Pengetahuan Usia Lanjut Tentang Pemanfaatan Posyandu Usila Di Puskesmas Wayamuli Kecamatan Rajabasa Kabupaten Lampung Selatan Tahun 2010, menunjukkan bahwa pemanfaatan posyandu usia lanjut dalam satu tahun terakhir yang terbanyak yaitu 7 kali sebanyak 62 orang dan paling sedikit memanfaatkan $<5$ kali yaitu sebanyak 15 orang $(12,5 \%)$ artinya bahwa masyarakat yang mempunyai keluarga usia lanjut menunjukkan bahwa kecenderungan pemanfaatan pelayanan kesehatan di posyandu usia lanjut sangat rendah, dan keaktifan usia lanjut dalam mengikuti kegiatan posyandu pun juga sangat rendah. 
Peneliti berasumsi bahwa sebagian besar responden masih memiliki pengetahuan kurang tentang pemanfaatan posyandu usia lanjut, hal ini diakibatkan oleh faktor pendidikan masyarakat yang rendah, dan tidak pernah mendapatkan informasi, yang akan berdampak terhadap rendahnya tingkat pengetahuan seseorang terhadap prilaku dan upaya kesehatan sehingga semakin rendah pula pemahamannya tentang posyandu usila dan semakin kurang juga keinginan untuk berkunjung ke posyandu usia lanjut.

2. Hubungan Dukungan Keluarga dengan Kegiatan Posyandu Lansia

Tabel 5

Hubungan Dukungan Keluarga dengan Kegiatan Posyandu Lansia (n=79)

\begin{tabular}{|c|c|c|c|c|c|c|c|c|}
\hline \multirow{4}{*}{ Dukungan Keluarga } & \multirow{2}{*}{\multicolumn{4}{|c|}{$\begin{array}{c}\text { Kegiatan Posyandu } \\
\text { Lansia }\end{array}$}} & \multirow{3}{*}{\multicolumn{2}{|c|}{ Jumlah }} & \multirow{4}{*}{\multicolumn{2}{|c|}{$\begin{array}{l}\frac{(\text { Chi-square })}{\mathrm{X}^{2} \text { tabel }=0,05} \\
\mathrm{X}^{2} \text { hitung }=0,001 \\
\mathrm{Df}=1\end{array}$}} \\
\hline & & & & & & & & \\
\hline & \multirow{2}{*}{\multicolumn{2}{|c|}{ Ada }} & \multirow{2}{*}{\multicolumn{2}{|c|}{ Tidak Ada }} & & & & \\
\hline & & & & & & & & \\
\hline & $\mathrm{F}$ & $\%$ & $\mathrm{~F}$ & & $\mathrm{~F}$ & $\%$ & $\mathrm{X}^{2}$ hitung & $\mathrm{X}^{2}$ tabel \\
\hline Mendukung & 6 & 30 & 14 & 70 & 20 & 100 & & \\
\hline Tidak Mendukung & 3 & 5,1 & 56 & 94,9 & 59 & 100 & 9,069 & 3,841 \\
\hline
\end{tabular}

Tabel diatas menunjukkan dari seluruh keluarga yang memberikan dukungan pada lansia, sebanyak $7 \%$ tidak mengikuti kegiatan posyandu lansia, sementara $30 \%$ mengikuti kegiatan posyandu. Sebaliknya dari seluruh keluarga yang tidak memberikan dukungan pada lansia, sebanyak $94,9 \%$ tidak mengikuti kegiatan posyandu lansia. Hasil uji beda proporsi dengan df $=1$ mengunakan uji Chi - Square $\left(\mathrm{X}^{2}\right)$ dengan tingkat kepercayaan $95 \%$ menunjukkan adanya hubungan Dukungan keluarga dengan kegiatan posyandu lansia di desa Seuriget $(\mathrm{p}=$ 0,007), dengan nilai $X^{2}$ hitung $=9,069$ $>\quad X^{2}=3,841$. Berdasarkan hasil penelitian diatas dapat disimpulkan bahwa terdapat hubungan antara dukungan keluarga dengan keikut sertaan usila dalam kegiatan posyandu lansia.

Hal ini sesuai dengan penelitian Wahono (2011), menunjukkan bahwa ada pengaruh dukungan keluarga dengan pemanfaatan posyandu lansia di Desa Gantungan Makamhaji Sukoharjo. 
Kunjungan oleh lansia yang didampingi keluarga sebanyak $67,7 \%$ dan yang datang sendiri tanpa didampingi keluarga sebanyak 32,3\%. Hal ini memperlihatkan kecendrungan pemanfaatan pelayanan kesehatan di posyandu lansia sangat rendah bila tidak didampingi oleh keluarga dan posyandu usila akan berjalan lancar jika keluarga usila mau mendampingi usila untuk melakukan posyandu usila.

John (2010) menyatakan bahwa dukungan keluarga merupakan hal yang paling penting untuk mempengaruhi seorang usila melakukan kunjungan posyandu lansia, karena dengan adanya dukungan keluarga berupa berpartisipasi mengantarkan lansia ke posyandu lansia serta mengingatkan jadwal posyandu lansia maka lansia menjadi semangat dan rutin untuk berkunjung ke posyandu lansia. Dukungan keluarga yaitu informasi verbal, sasaran, bantuan yang nyata atau tingkah laku yang diberikan oleh orangorang yang akrab dengan subjek didalam lingkungan sosialnya atau yang berupa kehadiran dan hal yang dapat memberikan keuntungan emosional atau pengaruh pada tingkah laku penerimaannya. Dalam hal ini orang yang merasa memperoleh dukungan sosial, secara emosional merasa lega diperhatikan, mendapat saran atau kesan yang menyenangkan pada dirinya (Zainudin, 2012). Dukungan keluarga seperti mengantarkan dan menemani lansia ke posyandu, mengingatkan jadwal posyandu dan menyakinkan lansia bahwa posyandu itu penting dapat mempengaruhi kunjungan ke posyandu lansia. Semakin banyak dukungan keluarga maka semakin banyak usia lanjut yang berkunjung ke posyandu lansia begitu juga sebaliknya, semakin sedikit dukungan keluarga maka semakin sedikit usia lanjut berkunjung ke posyandu lansia.

\section{SIMPULAN}

Hasil penelitian menunjukkan mayoritas responden tidak mengikuti posyandu lansia $(88,6 \%)$ karena kurangnya dukungan keluarga. Hasil penelitian menunjukkan bahwa mayoritas lansia tidak mengikuti kegiatan posyandu baik yang pengetahuannya cukup maupun kurang. Hasil penelitian menunjukkan lansia yang mendapatkan dukungan keluarga, mayoritas juga tidak mengikuti kegiatan posyandu lansia. Berdasarkan hasil penelitian diatas dapat disimpulkan bahwa terdapat 
hubungan dukungan keluarga dengan

kegiatan posyandu lansia. Hasil penelitian diharapkan dapat menjadi bahan masukan bagi masyarakat dan lansia terhadap pentingnya Posyandu lansia.

\section{DAFTAR RUJUKAN}

Bagus Ida. 2008. Memahami Kesehatan Reproduksi Wanita. Jakarta : Arcan.

Budi. 2008. Perubahan kejiwaaan pada wanita menopouse (online) (http://www.pdf.com, diakses, 12 Mai 2014).

Depkes RI. 2009. Undang-Undang Tentang Posyandu Usia Lanjut. (http://www.posyandu usila. com, diakses diakses, tanggal 10 Juni 2014).

Depkes RI. 2010. Antisipasi Pemerintah Membuat Posyandu Usia Lanjut. (http://www.posyandu usila. com, diakses diakses, tanggal 10 Juni 2014).

Depkes RI. 2012. Undang-Undang Posyandu Usia Lanjut. (http://www.posyandu usila. com, diakses, tanggal 10 Juni 2014).

Emy. 2012. Posyandu Lansia. (online) (http//www//boonemeemy.com, diakses tanggal 10 Juni 2014).

Erfandi. 2009. Pengelolaan Posyandu Lansia. (online) (http//www//puskesmas-oke.com, diakses tanggal 10 Juni 2014).

Frederick. 2008. Pengertian Pengetahuan. (online) (http//www//semianispyware.com, diakses tanggal 10 Juni 2014).

Hanum. 2009. Tujuan Posyandu Usila. (online)

(http//www//semianispyware.com, diakses tanggal 10 Juni 2014).

Horne. 2009. Pengertian Pengetahuan. (online)

(http//www//semianispyware.com, diakses tanggal 10 Juni 2014).

Jacoeb. 2012. Pengertian klimaterium (online)

(http//www//semianispyware.com, diakses tanggal 10 Juni 2014).

John. 2010. Pengertian Pendidikan, dan dukungan keluarga. (online) (http//www//semianispyware.com, diakses 11 Mai 2014.

Jones. 2011. Pengertian klimaterium (online)

(http//www//semianispyware.com, diakses tanggal 10 Juni 2014).

Mahyuliansyah. 2009. Posyandu Usila. (online)

(http//www//keperawatankomunit as.com, diakses tanggal 10 Juni 2014).

Marlyn. (2008). Jenis Dukungan Kluarga. (http//www//pdf.com, diakses tanggal 10 Juni 2014).

Notoadmodjo S. 2010. Metodologi Penelitian Kesehatan. Jakarta :Rineka Cipta.

Nugroho. (2009). Pendanaan dalam posyandu usila. (online) (http//www//semianispyware.com, diakses tanggal 10 Juni 2014).

Nugraha. 2010. Perubahan Fisiologis Usila. (online) (http//www//semianispyware.com, diakses tanggal 10 Juni 2014). 
Pramantara. 2011. Karakteristik Usia Lanjut. (http://www.pdf.com, diakses tanggal 10 Juni 2014.

Profil Dinas Kesehatan Aceh. 2012. Jumlah Usia Lanjut di Provinsi NAD, (online) (http://isearch.avg.com diakses tanggal 10 Juni 2014).

Profil Dinkes Kota Langsa. 2013. Jumlah Usila Kota Langsa.

Profil Puskesmas Langsa Barat. 2013. Jumlah Usila Kecamatan Langsa Barat.

Setiadi. 2011. Definisi Usia Lanjut .(online)

(http//www//semianispyware.com, diakses tanggal 10 Juni 2014).

Sigit. 2010. Pengetahuan Usia Lanjut Tentang Pemanfaatan Posyandu Usila Di Puskesmas Wayamuli Kecamatan Rajabasa Kabupaten Lampung Selatan Tahun. (online) (http//www//pdf.com, diakses tanggal 10 Juni 2014).

Sulaiman. 2012. Pengertian menopouse (online)

(http//www//semianispyware.com, diakses tanggal 10 Juni 2014).

Surini Sri. 2010. Fisioterapi Pada Lansia. Jakarta : EGC.

Sutarna. 2010. Definisi Usia Lanjut. (online) (http//www//semianispyware.com, diakses tanggal 10 Juni 2014).

Utomo. 2009. Proses Penuaan. (online) (http//www//semianispyware.com, diakses tanggal 10 Juni 2014).

Utami. 2009. Jenis Dukungan Kluarga. (http//www//pdf.com, diakses tanggal 10 Juni 2014).

Zainudin. 2012. Pengertian Dukungan Kluarga. $\quad($ http//www//pdf.com, diakses, 11 Mai 2014. 